Limnol. Rev. (2016) 16, 1: 15-25

\title{
Phosphorus in lake sediments of Poland - Results of monitoring research
}

\author{
Izabela Bojakowska
}

Polish Geological Institute - National Research Institute, Rakowiecka 4, 00-975 Warszawa, Poland, e-mail: iboj@pgi.gov.pl

\begin{abstract}
In 2010-2013, 528 samples of surface sediments were collected from the profundal zone of lakes to determine concentrations of phosphorus, $\mathrm{Al}, \mathrm{Ca}, \mathrm{Fe}, \mathrm{K}, \mathrm{Mn}, \mathrm{Na}$ and $\mathrm{S}$, as well as trace elements (As, $\mathrm{Ba}, \mathrm{Cd}, \mathrm{Co}, \mathrm{Cr}, \mathrm{Cu}, \mathrm{Mo}, \mathrm{Ni}, \mathrm{Pb}, \mathrm{Sn}, \mathrm{Sr}, \mathrm{Ti}, \mathrm{V}$ and $\mathrm{Zn}$ ) using the ICP-OES method. Additionally, Hg concentration (by the TMA method) and organic carbon concentration (using the coulometric titration method) were also determined. Phosphorus concentration was found to range from 0.005 to $1.925 \%$ ( $0.109 \%$ on average). High phosphorus concentrations in sediments were reported in lakes located within and around urban areas, in lakes on which recreation centres and leisure facilities are situated, and in lakes adjoining special protection areas of birds. The phosphorus concentration in sediments shows a clear correlation with the contents of $\mathrm{Al}, \mathrm{Fe}, \mathrm{Mn}, \mathrm{S}$ and TOC, which indicates the presence of phosphorus in both organic and inorganic forms. It also correlates with the contents of most of the trace elements examined for this study, including $\mathrm{Zn}, \mathrm{Hg}$ and $\mathrm{Pb}$. A certain regional variability was found; water sediments of lakes in the Masurian and Pomeranian lakelands, located in the area covered by the Pomeranian phase ice sheet, are characterised by a slightly higher phosphorus concentration compared with those from the Greater Poland Lakeland situated in the area of the Poznań phase glaciation.
\end{abstract}

Key words: phosphorus, lake sediments, geochemistry

\section{Introduction}

Phosphorus is the eleventh most common element in the Earth's crust, accounting for about $0.1 \%$ by weight. In the lithosphere it occurs almost exclusively as orthophosphates $\mathrm{PO}_{4}^{3-}$, forming more than 300 minerals. It is found mainly in the mineral apatite $\mathrm{Ca}_{5}\left[\mathrm{PO}_{4}\right]_{3}(\mathrm{~F}, \mathrm{Cl}, \mathrm{OH})$. It is also present in vivianite, variscite, wawellite, monazite and xenotime - for phosphate minerals are important not only because of their frequent occurrence but also for their economic significance. The average phosphorus concentration in igneous rocks ranges from $220 \mathrm{mg} \mathrm{kg}^{-1}$ (ultramafic rock) to $1200 \mathrm{mg} \mathrm{kg}^{-1}$ (basalt). In sedimentary rocks it varies between $30 \mathrm{mg} \mathrm{kg}^{-1}$ (sandstone) and $800 \mathrm{mg} \mathrm{kg}^{-1}$ (Reimann and Caritas 1998). The greatest amounts of phosphorus are contained in phosphates, in which more than half of the mass is represented by apatite, and in guano which is composed of calcium, magnesium and ammonium phosphates (e.g. struvite - $(\mathrm{NH})_{4} \mathrm{Mg}\left[\mathrm{PO}_{4}\right] \cdot 6 \mathrm{H}_{2} \mathrm{O}$ ). Phosphorus is an element essential for life: it is a component of the nucleic ac- ids DNA and RNA, transmitting genetic information, a constituent of compounds necessary for all organisms for the storage and supply of energy (ATP), and of compounds participating in metabolic processes (phosphorylation), as well as a component of phospholipids essential for the development of cells and their organelles (including lecithin that makes up cell membranes, and phytic acid which is a spare substance for phosphorus storage). It is also present in the form of hydroxyapatite in shells, bones and teeth.

Phosphorus is the first element for which a negative environmental impact was detected following the widespread use of its compounds in the economy, primarily as phosphate fertilizers and detergents (the problem of eutrophication of lakes was diagnosed in the 1960s). Phosphorus is considered a critical element in the circulation of matter in the lacustrine ecosystem, determining the status of its trophy (Søndergaard et al. 2003). Sediments play an important role in phosphorus circulation in lakes due to the accumulation/sorption of organic phosphorus compounds, with a concurrent reduction of its avail- 
ability in the water, and due to the release/desorption of phosphorus compounds available to producers and microbial heterotrophs. On the one hand, there is a continuous accumulation of phosphorus in lakes, caused by sedimentation of phosphate minerals imported from the catchment area, which most often occurs near the mouth of streams, by the sedimentation of allochthonous and autochthonous organic matter containing organic and inorganic phosphorus compounds, by the sorption of phosphates by components of the sediments - iron hydroxides and clay minerals, by the co-precipitation of phosphates with inorganic components (iron, manganese and carbonates), and by the formation of authigenic phosphate minerals, particularly hydroxyapatite and vivianite. On the other hand, phosphorus can be activated into water as a result of both a change in environmental conditions in the sediment (e.g. increased availability of oxygen) and microbial activity (Wetzel 2001). Research on the speciation of phosphorus in lake sediments and on bioavailability of particular forms has been conducted for many years because the supply of phosphorus from anthropogenic sources into lakes results in increased deposition of phosphorus in sediments., Excessive amounts of phospheorus can then be released into the water as a consequence of change in the physical, chemical or biological conditions, which in turn leads to eutrophication of the basin. A number of methods of reclamation of lake basins have also been developed in order to reduce the bioavailability of phosphorus from the sediments (Lewandowski et al. 2003; Reitzel et al. 2005; Gawrońska et al. 2007; Hickey and Gibbs 2009; Ruttenberg et al. 2009; Kowalczewska-Madura et al. 2010; Rzepecki 2010; Zhu et al. 2013).

The present study applies the results of monitoring research on sediments. Its purpose is to determine the variability of the occurrence of phosphorus in sediments of lakes in Poland, studied at the request of the Chief Inspector of Environmental Protection within the framework of the SEM subsystem (State Environmental Monitoring) - Monitoring of the quality of inland surface waters. These investigations include determination of the concentrations of potentially harmful constituents: heavy metals and selected hazardous organic compounds (permanent organic pollutants) in modern sediments that accumulate in the rivers and lakes of Poland. The determinations also include the concentrations of aluminum, calcium, magnesium, iron, manganese, phosphorus, sulphur and organic carbon - elements that are components of clay minerals, iron and manganese hydroxides, phosphates, carbonates, or sulphides. These can participate in the retention of contaminants in water sediments through co-precipitation or absorption.

\section{Geochemistry of phosphorus in lake sediments}

In lake sediments, phosphorus is present in the following forms: adsorbed phosphorus, non-apatite inorganic phosphorus, apatite phosphorus and organic phosphorus. Adsorbed phosphorus is the fraction that is most easily releasable from sediments and readily available to plants and microorganisms. Nonapatite inorganic phosphorus, co-precipitated with amorphous iron, manganese or aluminum hydroxides, is a phosphorus form that is most sensitive to changes of redox conditions, and readily bioavailable, as has been frequently indicated in publications (Burrus et al. 1990; Santiago and Thomas 1992). Organic phosphorus is associated with organic remains of allogenic and authigenic origin (proteins containing the nucleic acids DNA and RNA, phospholipids - lecithin, phytic acid, phosphatidic acid, humic compounds) (Riberiro et al. 2008; Xu et al. 2013; Zhu et al. 2013). It is believed that the main form of organic phosphorus in sediments is phytic acid (calcium-magnesium inositol hexakisphosphate) and phosphorus bound to proteins and fulvic acids. It has been found that insoluble $\mathrm{Fe}_{4}$-phytate can also form in sediments ( $\mathrm{Zhu}$ et al. 2013). The fraction of organic phosphorus is a resource from which phosphorus is slowly mobilized through the gradual decomposition of organic matter and organic phosphorus compounds by bacteria. Apatite phosphorus is present mainly in allogenic grains of the mineral apatite. In the surface sediment conditions, apatite phosphate is considered to be the stable and inert fraction of phosphorus, not prone to mobilization and unavailable for the biosphere, although apatite is soluble to some extent in an acidic environment. In addition to allogeneic apatite minerals, sediments also contain other authigenic phosphorus minerals, such as vivianite $\left(\mathrm{Fe}_{3}\left[\mathrm{PO}_{4}\right]_{2} \cdot 8 \mathrm{H}_{2} 0\right)$, cacoxenite $\left(\mathrm{Fe}_{24} \mathrm{AlO}_{6}\left[\mathrm{PO}_{4}\right]_{17}(\mathrm{OH})_{12} \cdot \mathrm{nH}_{2} \mathrm{O}\right)$, strengite $\left(\mathrm{Fe}\left[\mathrm{PO}_{4}\right] \cdot 2 \mathrm{H}_{2} \mathrm{O}\right)$, reddingite $\left(\mathrm{Mn}_{3}\left[\mathrm{PO}_{4}\right] \cdot 3 \mathrm{H}_{2} \mathrm{O}\right)$ and variscite $\left(\mathrm{Al}^{2}\left[\mathrm{PO}_{4}\right] \cdot 2 \mathrm{H}_{2} \mathrm{O}\right)$ (Moore and Reddy 1994; Łącka et al. 1998; Frederichs et al. 2003; Fagel et al. 2005; Taylor et al. 2008). The most important non-apatite mineral is vivianite, which is probably the most stable form of $\mathrm{Fe}^{2+}$ under reducing conditions. It precipitates from pore water during the early diagenesis of sediments (Nriagu and Dell 1974; Fagel et al. 2005; 
Taylor et al. 2008). It has been found that the solubility of authigenic minerals (strengite, vivianite, reddingite, hureaulite) in lake sediments depends on physicochemical parameters, such as $\mathrm{pH}$ and Eh, whereas the stability of hydroxyapatite and variscite is much less dependent on the redox conditions (Moore and Reddy 1994).

The concentration of phosphorus and the proportions of its various forms in lake sediments vary widely and depend on the specific conditions related to the lithology of the catchment area, its geomorphology, climate conditions, lake morphometry, depositional zone in the lake, physico-chemical conditions at the site of deposition, and, currently, to a very large extent on the land use across the catchment area. The phosphorus concentration in lake sediments varies from very low, close to the limit of determination of the analytical methods, to a few percent. For example, in sediment samples collected from the littoral zone of over 1,000 lakes in Poland, the phosphorus concentration was in the range between $<0.005$ and $0.801 \%$ (with an average of $0.028 \%$ ) (Lis and Pasieczna 1995). Much higher phosphorus concentrations are measured in sediments of eutrophic lakes contaminated by wastewater, e.g. up to $1.307 \%$ in Lake Nansihu (China) located in the city of Jining (Yang and Liu 2011). The proportions of various forms of phosphorus in sediments are highly variable, e.g. in sediments of Lake Koycegiz (Turkey), organic phosphorus accounts for $90 \%$ of total phosphorus, apatite phosphorus $-9 \%$, iron-bound phosphorus $-0.47 \%$, and calcium-bound phosphorus - $0.27 \%$ (Sahin et al. 2012). However, most reports point to the predominance of inorganic forms of phosphorus over its organic forms, e.g. in sediments of Lake Dongping (China), organic phosphorus accounts for $23.64-37.32 \%$ of total phosphorus, and inorganic phosphorus - 69.26-79.14\% (Chen S. et al.2011). Moreover in sediments of the lakes Volvi (Greece), Koronia (Greece), Taihu (China), Daming (China), Mochou (China) and Mogan (Turkey), sediments are dominated by the inorganic phosphorus fraction (Kaiserli et al. 2002; Fytianos and Kotzakioti 2005; Pulatsü et al. 2008; Wang et al. 2008; Xu et al. 2013). There is variability in the occurrence of organic and inorganic phosphorus in the vertical section. The surface layers are dominated by organic phosphorus, and the deeper parts - by apatite phosphorus (Kisand 2005; Chen et al. 2011).

Phosphorus can be released from sediments as a result of a variety of physical, chemical and bi- ological processes. The factors governing the release of phosphorus from sediments are: redox conditions, $\mathrm{pH}$, temperature and salinity, adsorption, solubility of the mineral phase, concentrations of dissolved oxygen, sulphates and nitrates, organic matter mineralization, and microbial activity (Christophordis and Fytianos 2006; Ribeiro et al. 2008; Ahlgren et al. 2011; Ditrich et al. 2013;). An increase of $\mathrm{pH}$ causes a decrease in the amount of iron-bound phosphates (Koski-Vähälä and Hartikainen 2001). In highly acidic lakes, pH affects the solubility of apatite, while in alkaline lakes the release of phosphorus is controlled by the aluminum content. Sorption of phosphates by clay minerals and hydrated iron and aluminum oxides is dependent on $\mathrm{pH}$. One of the factors affecting the release of phosphorus from sediments is the presence of anoxic conditions in the sediments and bottom waters (Cerco 1989). The availability of oxygen is the most decisive factor in the release of phosphorus from sediments; under reducing conditions the release of phosphorus is 5-10 times higher than in an oxidizing environment, in similar conditions (Ahlgren et al. 2011). In a reducing environment, where there is significant reduction of sulphates and iron, and hydrogen sulphide is formed, iron sulphides can precipitate, accompanied by a simultaneous release of phosphates that were previously bound to iron oxides. As a consequence, it increases the availability of phosphorus (which is a critical component for primary production in lakes) which results in an increase in eutrophic conditions within the lake (Kleeberg 1997; Holmer and Storkholm 2001). An increase in temperature accelerates chemical processes and the growth of organisms, stimulating decomposition of organic matter. The effect of temperature is best visible in lakes rich in iron compounds. The release of phosphorus from sediments is controlled by a combination of many factors, of which the most important are: concentration of dissolved oxygen, concentration of sulphates in the water/sediment layer, rate of phosphorous immobilization in a reducing environment, and sedimentation of iron and organic matter (Katsev et al. 2006). What is important is the Fe:P ratio in the sediments. It is believed that the Fe:P ratio may be indicative of potential mobilization of orthophosphate ions bound to iron hydroxides in sediments. A value of this ratio greater than 15 may indicate the possibility of effective control of the internal supply of phosphates (Jensen et al. 1992; Lopez et al. 2006). The presence of aluminum hydroxides in sediments, and partial stability of the trivalent iron 
compounds prevents the release of phosphorus from the sediment, even under reducing conditions, and the phosphorus released from iron minerals rapidly binds to hydroxides of other elements (Hupfer and Lewandowski 2008).

\section{Scope and Methods}

The lake sediments examined within the framework of National Environmental Monitoring were sampled from selected lakes covered by the regional monitoring network that includes 1032 lakes with an area of more than 50 ha, smaller lakes important ecologically or economically, and 22 benchmark lakes of the national lake monitoring network. Every year, approximately 130 samples of lake sediments are collected and analysed. The analyses are performed on samples collected from surface sediments of the profundal zone. In 2010-2013, 528 samples of sediments from 352 lakes were collected throughout Poland (Fig. 1). Sediment samples were taken using the Van Veen sampler.

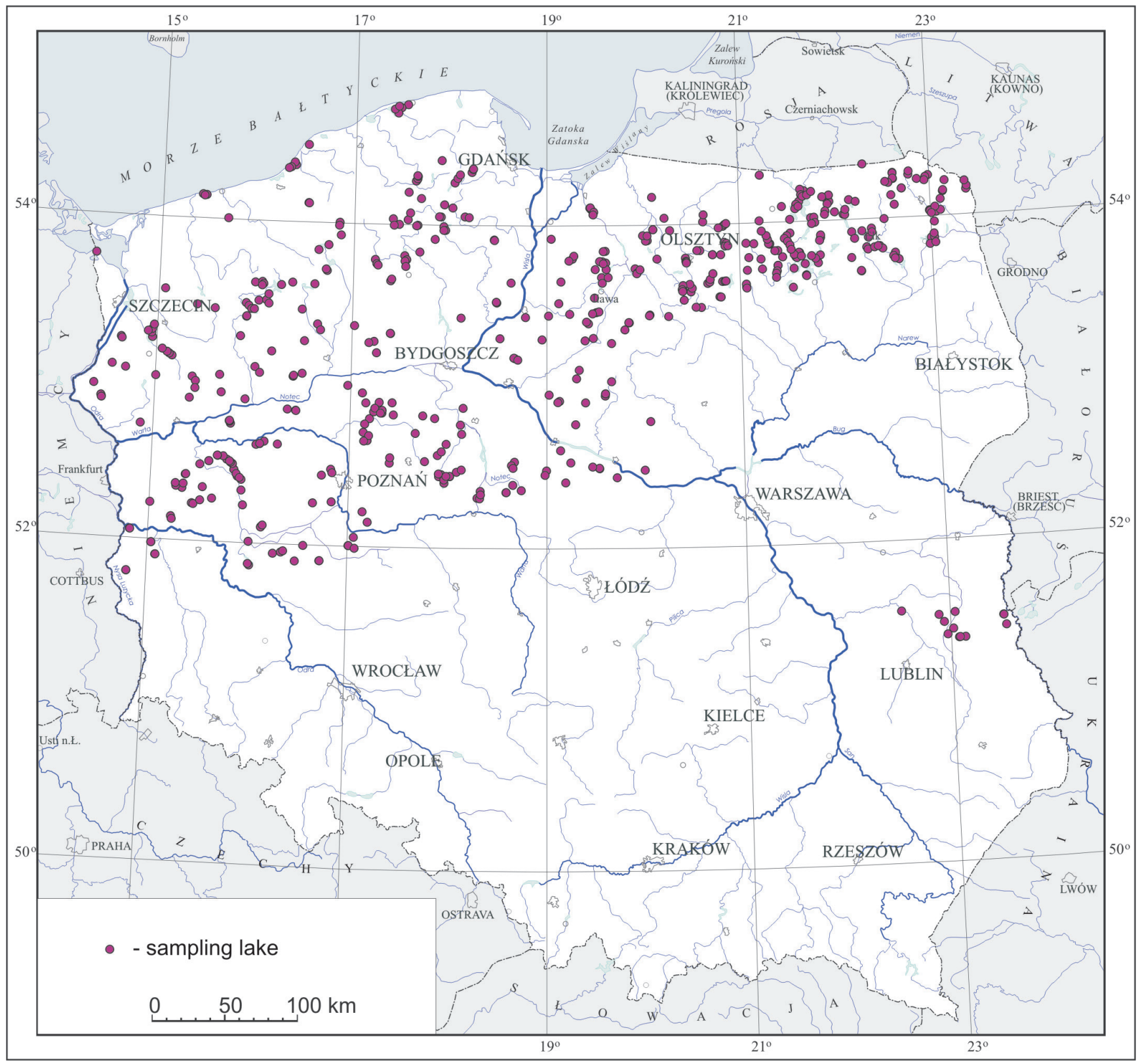

Fig. 1. Location of the sampled lakes 
The samples ( $<0.2 \mathrm{~mm}$ fraction) were digested by aqua regia (1-gramme sample, $50 \mathrm{~g} \mathrm{HCl}+\mathrm{HNO}_{3}$ ) and analysed for concentrations of sulphur as well as As, Ba, Ca, Cd, Co, Cr, Cu, Fe, K, Mn, Mo, Na, Ni, $\mathrm{P}, \mathrm{Pb}, \mathrm{Sn}, \mathrm{Sr}, \mathrm{Ti}, \mathrm{V}$ and $\mathrm{Zn}$ using inductively coupled plasma atomic emission spectrometry (Thermo Scientific iCAP6500 spectrometer). The limits of determination for the individual elements were as follows: $\mathrm{Ag}$, $\mathrm{Cd}$ and $\mathrm{Mo}-0.5 \mathrm{mg} \mathrm{kg}^{-1}$; $\mathrm{Ba}, \mathrm{Co}, \mathrm{Cr}, \mathrm{Cu}, \mathrm{Mn}, \mathrm{Ni}, \mathrm{Sr}$ and $\mathrm{Zn}-1 \mathrm{mg} \mathrm{kg}^{-1}$; $\mathrm{Sn}$ and $\mathrm{Pb}-2 \mathrm{mg} \mathrm{kg}^{-1}$; $\mathrm{As}-3 \mathrm{mg}$ $\mathrm{kg}^{-1}$; $\mathrm{P}$ and $\mathrm{S}-0.005 \%$; $\mathrm{Al}, \mathrm{Ca}, \mathrm{Fe}$ and $\mathrm{Mg}-0.01 \%$. Additionally, the samples were analysed for organic carbon content (TOC) using the coulometric titration method (Strohlein Coulomat 702 CS/LI), and for Ag using atomic absorption spectroscopy (Altec AMA 254 spectrometer). The limit of determination for TOC was $0.10 \%$, and for $\mathrm{Hg}-0.001 \mathrm{mg} \mathrm{kg}^{-1}$. All analyses were performed at the Central Chemical Laboratory NRI accredited (Certificate of Accreditation AB 283 Polish Centre for Accreditation). In order to assess the research quality, reference lake sediment material WQB-3 was also analysed (Certified Reference Sediments for Total Trace Elements from the National Laboratory for Environmental Testing in Burlington, National Water Research Institute in Canada).

To determine the statistical parameters of major elements and correlation coefficients for the analysed elements, and to develop histograms and scatter plots for the concentrations of phosphorus and some other elements and parameters, STATISTICA software was used.

\section{Results and Discussion}

The phosphorus concentration in the lake sediments ranges from $<0.005$ to $1.925 \%$, and the average value is $0.109 \%$, geometric mean $-0.089 \%$, and the median $-0.089 \%$ (Table 1 ). These values are close to the average phosphorus concentration in stream sediments of northern Poland, but are over three times greater than the geometric mean of phosphorus concentration in lake sediments of the littoral zone (Lis and Pasieczna 1995; Salminen et al. 2005). A histogram of phosphorus concentration in the lake sediments shows that most samples form a population with a distribution similar to normal distribution in the range of phosphorus concentration up to $0.2 \%$ (Fig. 2). Phosphorus concentrations greater than $0.2 \%$ were found in sediments of 44 lakes $(8.33 \%$ of all samples), but there was only one case where the concentration was above $0.6 \%$ (Table 2 ).

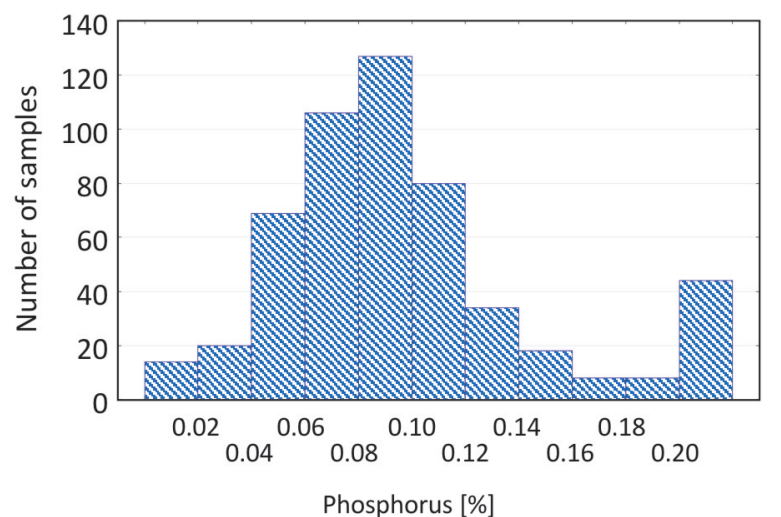

Fig. 2. Histogram of the phosphorus concentration in lake sediments

Table 1. Statistics of major elements in lake sediments $(n=528)$. Concentration values are given in percents

\begin{tabular}{|c|c|c|c|c|c|c|}
\hline Element & Mean & $\begin{array}{l}\text { Geometric } \\
\text { mean }\end{array}$ & Median & Minimum & Maximum & $\begin{array}{l}\text { Standard } \\
\text { deviation }\end{array}$ \\
\hline Phosphorus & 0.109 & 0.088 & 0.089 & 0.005 & 1.93 & 0.110 \\
\hline Aluminium & 0.50 & 0.37 & 0.39 & 0.04 & 2.23 & 0.39 \\
\hline Manganese & 0.093 & 0.065 & 0.071 & 0.003 & 1.18 & 1.025 \\
\hline Sulphur & 1.09 & 0.862 & 0.996 & 0.023 & 4.63 & 0.686 \\
\hline Calcium & 13.2 & 8.63 & 13.4 & 0.05 & 30.6 & 8.45 \\
\hline Organic carbon & 7.99 & 6.52 & 6.80 & 0.19 & 33.1 & 4.91 \\
\hline Iron & 1.55 & 1.26 & 1.41 & 0.05 & 10.9 & 1.03 \\
\hline Iron/Phosphorus & 17.7 & 15.3 & 16.2 & 3.1 & 180 & 11.9 \\
\hline Manganese/Phosphorus & 0.9 & 0.8 & 0.8 & 0.1 & 8.3 & 0.77 \\
\hline Aluminium/Phosphorus & 6.1 & 4.7 & 4.8 & 0.8 & 29.7 & 4.77 \\
\hline Calcium/Phosphorus & 176 & 107 & 137 & 3.5 & 2534 & 177 \\
\hline
\end{tabular}


Table 2. Summary of lakes with high phosphorus concentrations in sediments

\begin{tabular}{|c|c|c|}
\hline \multirow{2}{*}{ Lake } & \multirow{2}{*}{ Province } & Phosphorus \\
\hline & & [\%] \\
\hline Boczne & Podlachia & 0.449 \\
\hline Charzykowskie & Pomerania & 0.510 \\
\hline Dłużec & Warmia-Masuria & 0.344 \\
\hline Drwęckie & Warmia-Masuria & 0.484 \\
\hline Karczemne & Pomerania & 1.925 \\
\hline Krępsko Długie & Greater Poland & 0.437 \\
\hline Lubinieckie (Poznańskie) & Greater Poland & 0.400 \\
\hline Lucieńskie & West Pomerania & 0.445 \\
\hline Rajgrodzkie & Warmia-Masuria & 0.377 \\
\hline Szczytno & Pomerania & 0.447 \\
\hline Tumiańskie & Warmia-Masuria & 0.595 \\
\hline Urzędowe (Człuchowskie) & Pomerania & 0.347 \\
\hline
\end{tabular}

The greatest phosphorus concentration - almost $2.0 \%$ - was recorded in the sediments of highly polluted Lake Karczemne, located within the town of Kartuzy (population approx. 15,000). The sediments of another lake located near Kartuzy - Lake Klasztorne - are also characterised by a clearly elevated phosphorus concentration $(0.281 \%)$. A high phosphorus concentration is also reported from the sediments of Lake Drwęckie $(0.488 \%)$, located in part within the boundaries of the town of Ostróda, population 34,000. A very high phosphorus concentration was found in the sediments of Lake Tumińskie (0.595\%), surrounded by numerous resorts and recreational facilities on its shore. The presence of high phosphorus concentrations in sediments, caused by the discharge of sewage into lakes located in urban areas, is reported in many publications: e.g. the phosphorus concentrations in the sediments of Lake Doming and Lake Mochou (China) are greater than $1.0 \%$, and in the sediments of Lake Genewa (USA) - 1.6\% (Wang et al. 2008; Elder et al. 2000). High phosphorus concentrations have been found in lake sediments in Ethiopia, e.g. in Lake Arbi $(0.4 \%)$, and in Lake Ruusmae $\left(0.52 \mathrm{mg} \mathrm{kg}^{-1}\right.$ ) (Kisand 2005).

Particularly noteworthy is the high phosphorus concentration in the sediments of the following lakes: Charzykowskie (0.510\%), Druzno $(0.265 \%)$ and Szczytno $(0.388 \%)$, adjoined by special protection areas for birds. High phosphorus concentrations in the sediments of Lake Krępsko Długie are undoubtedly related to the existing connection with Lake Szczytno.
Bird droppings are a good source of phosphate fertilizers (guano). Bird excrement, especially of fish-eating birds, typically has a very high content of phosphorus. For example, cormorant droppings contain $14.32 \% \mathrm{P}$, and those of herons $-11.47 \%$ (for comparison, stork excrement contains $0.79 \% \mathrm{P}$ ) (Marion et al. 1994). The problem of eutrophication of water bodies as a result of temporary inhabitation by migrating birds is widely discussed in literature. Visits of bird flocks, sometimes numbering more than one million individuals, result in introducing significant loads of phosphorus into lakes, which causes eutrophication of these water bodies. For example, $70 \%$ of phosphorus is introduced by migratory birds into Lake Wintergreen (Canada), and into Lake Grand-Lieu (France) - even up to as much as 95\% (Manny et al. 1994; Marion et al., 1994). The high levels of phosphorus observed in lakes Charzykowskie, Drużno, Szczytno and Krepsko Długie, where bird reserves are located, are undoubtedly the result of the activity of numerically large bird colonies, in particular cormorants and herons.

The lake sediments show a slight regional variability of phosphorus concentration. Lake sediments in the Masurian and Pomeranian lakelands have a slightly higher content of this element (the averages are $0.092 \%$ and $0.088 \%$, respectively) compared to lake sediments in the Greater Poland Lakeland (average $-0.082 \%)$. The Masurian and Pomeranian lakes are located in the area of the Pomeranian phase glaciation, whereas the Greater Poland lakes occur in the area covered by deposits of the Poznan phase glaciation (Fig. 3). The variability is a consequence of the diverse mineral composition of the deposits of these two glaciations.

Phosphorus concentration in lake sediments shows a clear correlation with the concentrations of $\mathrm{Al}$ $(\mathrm{r}=0.27), \mathrm{Fe}(\mathrm{r}=0.44), \mathrm{Mn}(\mathrm{r}=0.30), \mathrm{S}(\mathrm{r}=0.44)$ and TOC ( $r=0.41)$ (Table 3). A good correlation between the phosphorus contents and the organic carbon and sulphur contents in the lake sediments, as well as the scatter plots for these elements (Fig. 4) indicate that a large portion of phosphorus in the sediments is associated with organic matter. Scatter plots for the concentrations of phosphorus, calcium, iron, manganese and aluminum confirm and illustrate the good correlation between phosphorus and $\mathrm{Fe}, \mathrm{Mn}$ and $\mathrm{Al}$, which is related to the fact that these elements are present in sediments mostly either in the form of hydroxides, characterised by the ability to retain phosphate, or in authigenic phosphates of these elements. The lack of 


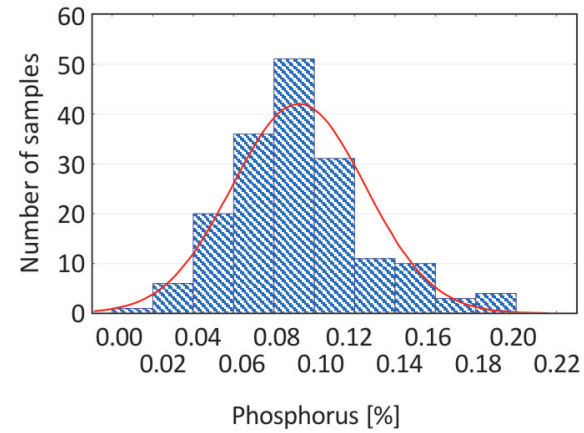

Masurian Lakeland

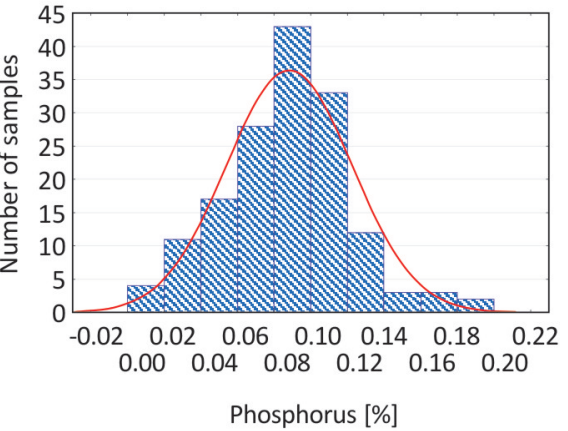

Pomeranian Lakeland

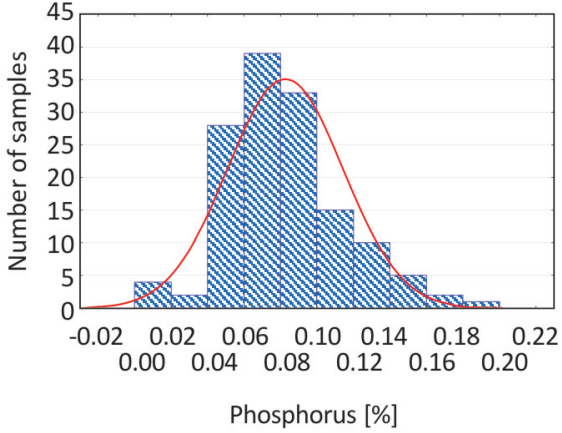

Greater Poland Lakeland

Fig. 3. Histograms of the phosphorus concentration in lake sediments of the Masurian, Pomeranian and Greater Poland lakelands

Table 3. Correlation coefficients of phosphorus with major and trace elements in lake sediments $(n=485, p=0.05)$. Values of significant correlation coefficients are given in bold

\begin{tabular}{lclclc}
\hline \multicolumn{1}{c}{ Element } & $\begin{array}{c}\text { Correlation } \\
\text { coefficient }\end{array}$ & \multicolumn{1}{c}{ Element } & $\begin{array}{c}\text { Correlation } \\
\text { coefficient }\end{array}$ & Element & $\begin{array}{c}\text { Correlation } \\
\text { coefficient }\end{array}$ \\
\hline Aluminium & $\mathbf{0 . 2 6}$ & Silver & $\mathbf{0 . 1 4}$ & Molybdenum & $\mathbf{0 . 2 1}$ \\
\hline Calcium & 0.02 & Arsenic & $\mathbf{0 . 1 8}$ & Nickel & $\mathbf{0 . 3 5}$ \\
\hline Iron & $\mathbf{0 . 4 1}$ & Bar & $\mathbf{0 . 3 2}$ & Lead & $\mathbf{0 . 3 8}$ \\
\hline Potassium & $\mathbf{0 . 1 0}$ & Cadmium & $\mathbf{0 . 3 5}$ & Tin & $\mathbf{0 . 3 0}$ \\
\hline Magnesium & $\mathbf{0 . 1 0}$ & Cobalt & $\mathbf{0 . 2 9}$ & Strontium & 0.01 \\
\hline Manganese & $\mathbf{0 . 3 1}$ & Chromium & $\mathbf{0 . 1 4}$ & Titanium & 0.07 \\
\hline Sulphur & $\mathbf{0 . 4 5}$ & Copper & $\mathbf{0 . 1 2}$ & Vanadium & $\mathbf{0 . 3 4}$ \\
\hline Organic carbon & $\mathbf{0 . 3 7}$ & Mercury & $\mathbf{0 . 5 0}$ & Zinc & $\mathbf{0 . 5 2}$ \\
\hline
\end{tabular}
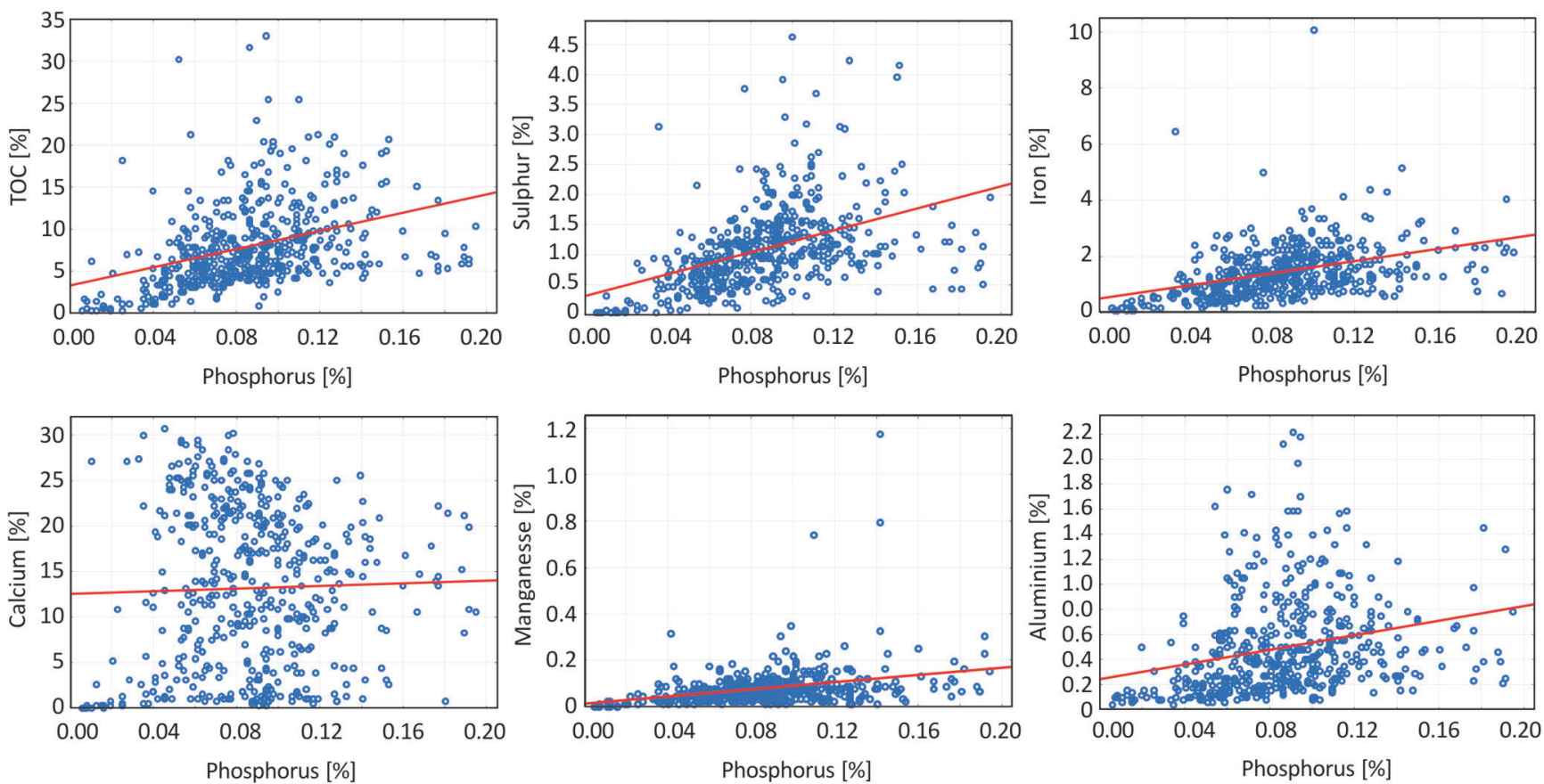

Fig. 4. Scatter plots for the concentration of phosphorus with organic carbon, sulphur, iron, calcium, manganese and aluminum $(\mathrm{n}=$ 485) 
correlation between the concentrations of phosphorus and calcium (Table 3 and Fig. 3 ) is caused by a very high concentration of calcium in the sediments primarily in the form of calcium carbonate, whose content is much higher than the content of hydroxyapatite. Phosphorus concentration also correlates with the contents of most of the trace elements examined during the study, including the concentration of $\mathrm{Zn}$ $(\mathrm{r}=0.52), \mathrm{Hg}(\mathrm{r}=0.50)$ and $\mathrm{Pb}(\mathrm{r}=0.35)$, indicating the possibility of binding these heavy metals as phosphates.

It is interesting to examine the variability of the Fe:P, Mn:P and Al:P ratios in the lake sediments (Fig. 5). The Fe:P ratio varies from 3 to 180, and the average value is 18. For comparison, the Fe:P ratio in the sediments of Lake Mogan (Turkey) ranges from 18.5 to 53.1, Lake Koronia - 12, and Lake Volvi - 4.5 (Kaiserli et al. 2002; Pulatsü et al. 2008). The Mn:P ratio varies between 0.1 and 8.3 (1.0 on average), and the Al:P ratio falls into the interval of $0.8-30$ (6 on average). The ratios notably increase with the increase of iron, manganese and aluminum contents in the sediments. The correlation coefficient for the $\mathrm{Fe}: \mathrm{P}$ ratio to the iron content is 0.74 , for the $\mathrm{Mn}: \mathrm{P}$ ratio to the manganese content -0.84 , and for the $\mathrm{Al}: \mathrm{P}$ ratio to the aluminum content -0.83 . Concurrently, the relationships between the Fe:P, Mn:P and Al:P values and phosphorus concentration in the sediments are much weaker, and the correlation coefficients are $-0.16,-0.15$ and -0.20 , respectively (Table 4 ). It can thus be concluded that the Fe:P, Mn:P and Al:P ratios calculated for the individual sediments depend largely on the contents of iron, manganese and aluminum, and therefore on local conditions. To a much lesser extent, the Fe:P, Mn:P and $\mathrm{Al}: \mathrm{P}$ ratios depend on phosphorus concentration in the sediments. The Fe:P, Mn:P and $\mathrm{Al}: \mathrm{P}$ ratios result from the availability of these components in the sediments and pore water, from the sorption of phosphate by $\mathrm{Fe}, \mathrm{Mn}$ and $\mathrm{Al}$ hydroxides, and from the presence of authigenic phosphates such as vivianite, strengite, reddingite, variscite and wavellite. The Fe:P, Mn:P and $\mathrm{Al}: \mathrm{P}$ ratios in the sediments are probably more dependent on the formation of authigenic minerals than on sorption by hydroxides, considering that, for instance, the sorption capacity of iron hydroxides and goethite is estimated at $24 \mathrm{mg} \mathrm{g}^{-1}(\mathrm{Fe}: \mathrm{P}$ ratio $=44)$, and the Fe:P ratio in vivianite is much lower - 2.6. This supports the view of Katsev et al. (2006) that the retention of phosphorus in sediments occurs rather due to its retention in the solid phase than due to the sorption process.

The relationship between the concentrations of calcium and phosphorus in the lake sediments is different: there is no correlation (Table 3 and Fig. 4). A lack of correlation between the concentrations of calcium and phosphorus is also observed in sediments of other lakes (Fytianos and Kotzakioti 2005). However, the analyses prove that although the concentrations of these elements show no correlation, the Ca:P ratio exhibits a very good positive correlation with the calcium concentration $(\mathrm{r}=0.72)$ and a negative correlation with the phosphorus concentration $(\mathrm{r}=-0.35)$ in the sediments. The absence of a simple relationship between the concentrations of $\mathrm{Ca}$ and $\mathrm{P}$ is caused by the presence of calcium in the sediments, primarily in the form of carbonate, in a much lower proportion of authigenic hydroxyapatite.

\section{Conclusions}

Phosphorus concentration in lake sediments was found to range from 0.005 to $1.925 \%$, and the av-

Table 4. Correlation coefficients of $\mathrm{Al}, \mathrm{Ca}, \mathrm{Fe}$ and $\mathrm{Mn}$ with the Al:P, Ca:P, Fe:P and Mn:P ratios in lake sediments ( $\mathrm{n}=528, \mathrm{p}=0.05)$. Values of significant correlation coefficients are given in bold

\begin{tabular}{|c|c|c|c|c|c|c|c|c|c|}
\hline & $\mathrm{Al}$ & $\mathrm{Ca}$ & $\mathrm{Fe}$ & $\mathrm{Mn}$ & $\mathrm{P}$ & Al.:P & Ca:P & Fe:P & $M n: P$ \\
\hline $\mathrm{Al}$ & 1.00 & -0.58 & 0.51 & -0.08 & 0.26 & 0.84 & -0.47 & 0.30 & -0.22 \\
\hline $\mathrm{Ca}$ & -0.58 & 1.00 & -0.32 & 0.21 & -0.01 & -0.61 & 0.71 & -0.29 & 0.29 \\
\hline $\mathrm{Fe}$ & 0.51 & -0.32 & 1.00 & 0.29 & 0.44 & 0.32 & -0.35 & 0.70 & 0.11 \\
\hline $\mathrm{Mn}$ & -0.08 & 0.21 & 0.29 & 1.00 & 0.30 & -0.20 & 0.03 & 0.06 & 0.81 \\
\hline$P$ & 0.26 & -0.01 & 0.44 & 0.30 & 1.00 & -0.18 & -0.35 & -0.17 & -0.13 \\
\hline Al.:P & 0.84 & -0.61 & 0.32 & -0.20 & -0.18 & 1.00 & -0.37 & 0.42 & -0.18 \\
\hline Ca:P & -0.47 & 0.71 & -0.35 & 0.03 & -0.35 & -0.37 & 1.00 & -0.11 & 0.29 \\
\hline Fe:P & 0.30 & -0.29 & 0.70 & 0.06 & -0.17 & 0.42 & -0.11 & 1.00 & 0.19 \\
\hline$M n: P$ & -0.22 & 0.29 & 0.11 & 0.81 & -0.13 & -0.18 & 0.29 & 0.19 & 1.00 \\
\hline
\end{tabular}


erage value is $0.109 \%$, the geometric mean $-0.089 \%$, and the median $-0.089 \%$. These values are close to the average phosphorus concentration in stream sediments of northern Poland, but more than three times greater than the geometric mean of phosphorus concentration in lake sediments of the littoral zone.

High phosphorus concentrations were found in

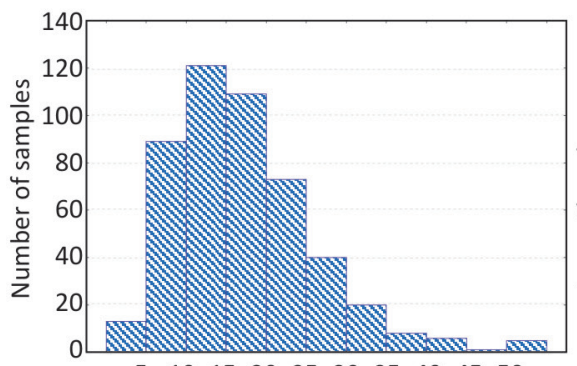

5101520253035404550 Iron : Phosphorus

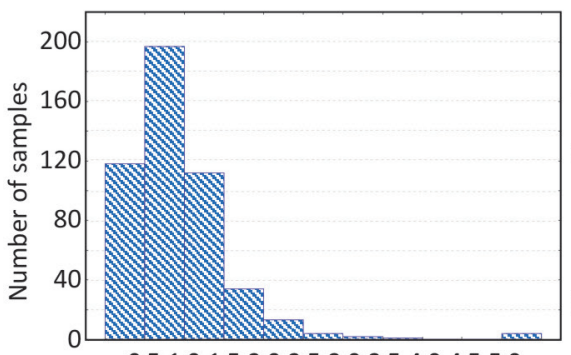

0.51 .01 .52 .02 .53 .03 .54 .04 .55 .0

Manganese : Phosphorus
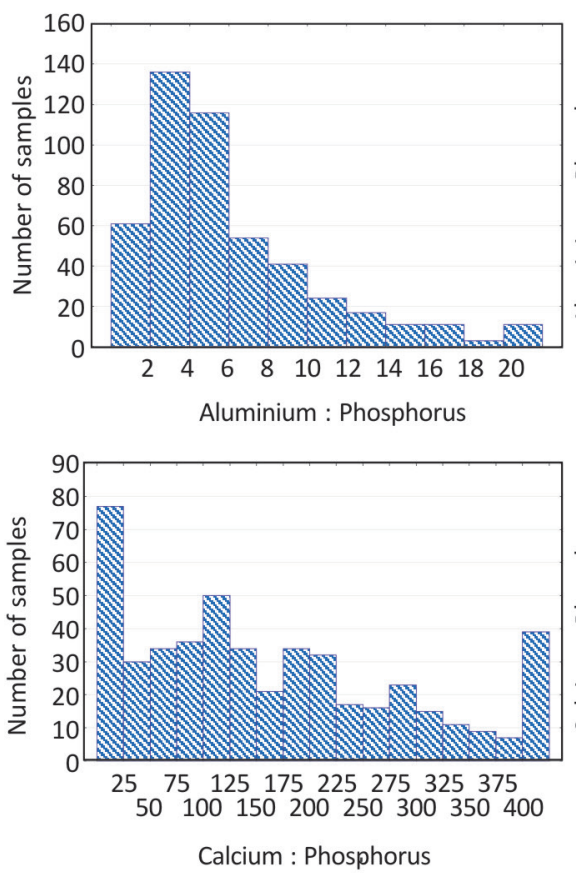

sediments of lakes located within or near urban areas (e.g. Lake Drwęckie - 0.488\%, Lake Karczemne $1.925 \%$, Lake Klasztorne - 0.281\%, Lake Lublinieckie $-0.400 \%)$, in sediments of some lakes on which recreation centres and leisure facilities are situated (e.g. Lake Tumińskie $-0.595 \%$ ), and in sediments of lakes adjoining special protection areas for birds (e.g. Lake Charzykowskie - 0.510\%, Lake Druzno - 0.265\%,
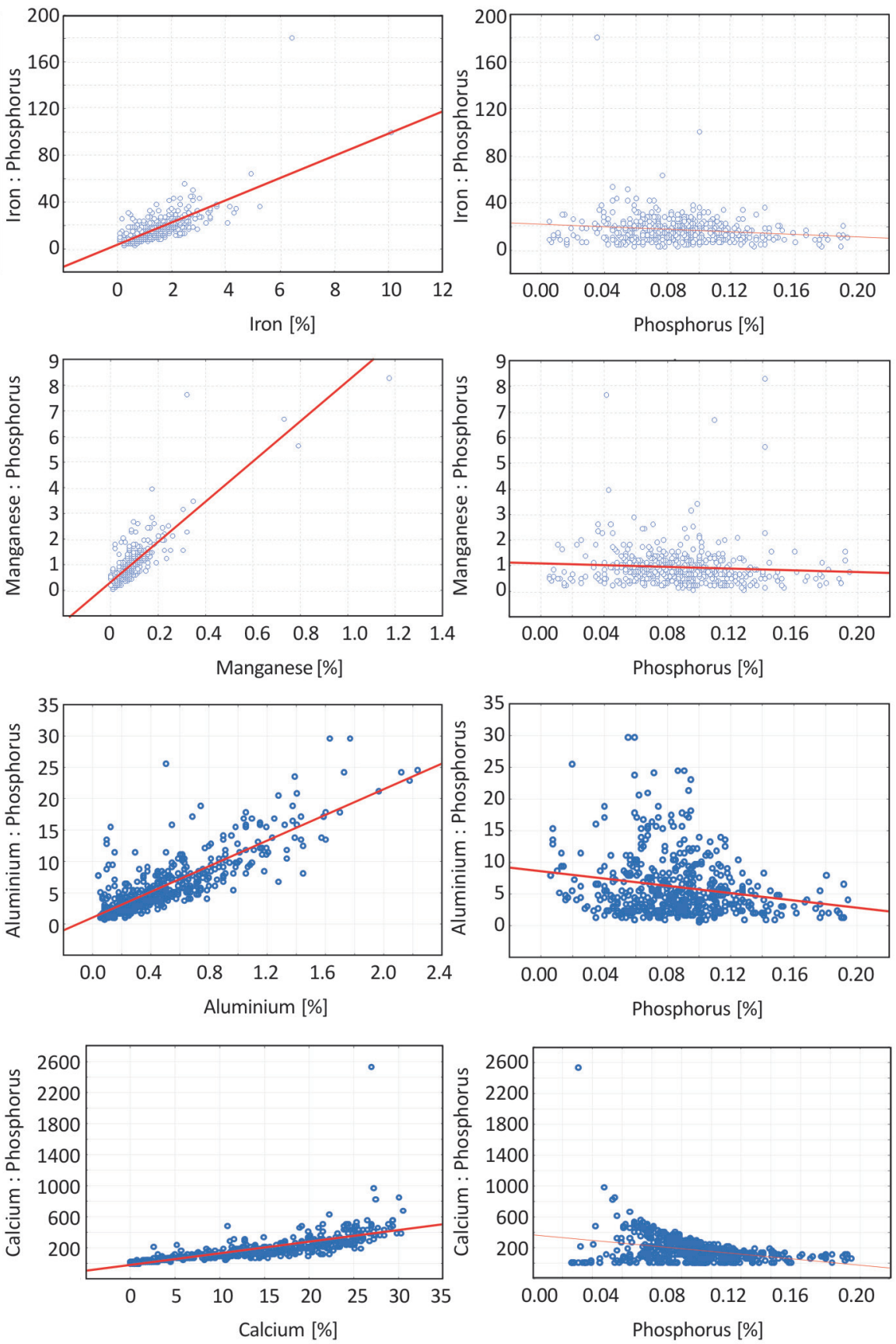

Fig. 5. Histograms and scatter plots for the Al:P, Ca:P, Fe:P and Mn:P ratios 
Lake Szczytno - 0.388\%).

The phosphorus concentration in lake sediments shows a clear correlation with the concentrations of $\mathrm{Al}(\mathrm{r}=0.27), \mathrm{Fe}(\mathrm{r}=0.44), \mathrm{Mn}(\mathrm{r}=0.30)$, $\mathrm{S}(\mathrm{r}=0.44)$ and TOC $(\mathrm{r}=0.41)$, which indicates the presence of phosphorus in both organic (sulphur and organic carbon) and inorganic (aluminum, iron and manganese) forms. The phosphorus concentration also shows a correlation with the concentrations of most of the analysed trace elements, e.g. $\mathrm{Zn}(\mathrm{r}=0.52)$, $\mathrm{Hg}(\mathrm{r}=0.50)$ and $\mathrm{Pb}(\mathrm{r}=0.35)$.

A slight regional variability was observed: lake sediments in the Masurian and Pomeranian lakelands, located in the area of the Pomeranian phase glaciation, are characterised by a slightly higher content of phosphorus in comparison the lake sediments in the Greater Poland Lakeland covered by deposits of the Poznań phase glaciation.

\section{References}

Ahlgren J., Reitzel K, De Brabandere H, Gogoll A, Rydin E., 2011, Release of organic P forms from lake sediments, Water Res. 45(2):565-72.

Burrus D., Thomas R. L., Dominik, Vernet J. P., 1990, Seasonal delivery of the particulate forms of phosphorus to Lake Geneva from the upper Rhone river, Aquat. Sci. 52(3): 221-235.

Cerco C. F., 1989, Measured and modelled effects of temperature, dissolved oxygen and nutrient concentration on sediment-water nutrient exchange, Hydrobiologia 174: 185-94.

Chen S., Chen Y., Liu J., Zhang J., Wu A., 2011, Vertical variation of ohosphorus form in core sediments from Dongping Lake, China, Procedia Environ. Sci. 10: 1797-1801.

Christophoridis C., Fytianos K., 2006, Conditions affecting the release of phosphorus from surface lake sediments, J. Environ. Qual. 35: 1181-1192.

Ditrich M., Chesnyuk A., Gudimov A., McCulloch J., Quazi S., Young J., Winter J., Stainsby E., Arhonditsis G., 2013, Phosphorus retention in mesotrophic lake under transient loading conditions: Insights from a sediment phosphorus binding form study, Water Res. 47: 1433-1447.

Elder J.F., Robertson D.M., Garrison P.J., 2000, Chemical Composition of Surficial Sediment in Geneva Lake, Wisconsin, U.S. Geological Survey Fact Sheet FS-121-00: 1-4. Retrieved from http://wi.water.usgs.gov/pubs/fs121-00/fs-121-00.pdf

Fagel N., Alleman L.Y., Granina L. Hatert F., Thamo-Bozso E., Cloots R., Andre L., 2005, Vivianite formation and distribution in Lake Baikal sediments, Glob. Planet. Change 46: 315-336.

Frederichs T. von Dobeneck T., Bleil U, Dekkers M.J., 2003, Towards the identification of siderite, rhodochrosite, and vivianite in sediments by their low-temperatu- re magnetic properties, Phys. Chem. Earth 28: 669-679.

Fytianos K., Kotzakioti A., 2005, Sequential fractionation of phosphorus in lake sediments of northern Greece, Environ. Monit. Assess. 100:191-200.

Gawrońska H., Łopata M., Jaworska B., 2007, The effectiveness of the phosphorus inactivation method in reducing the trophy of lakes of different morphometric and hydrological features, Limnol. Rev. 7(1): 27-34.

Hickey C., Gibbs M., 2009, Lake sediment phosphorus release management - Decision support and risk assessment framework, New Zeal. J. Marine Freshwat. Res. 43: 819-856.

Holmer M., Storkholm P., 2001, Sulphate reduction and sulphur cycling in lake sediments: a review, Freshwat. Biol. 46: 431-451.

Hupfer M., Lewandowski J., 2008, Oxygen Controls the Phosphorus Release from Lake Sediments - a LongLasting Paradigm in Limnology, Internat. Rev. Hydrobiol. 93 (4-5): 415-432.

Jensen H.S., Kristensen P., Jeppesen E., Skytthe A., 1992, Iron:phosphorus ratio in surface sediment as an indicator of phosphate release from aerobic sediments in shallow lakes, Hydrobiologia 235/236: 731-743.

Kaiserli, A., Voutsa, D., Samara, C., 2002, Phosphorus fractionation in lake sediments - Lakes Volvi and Koronia, N. Greece, Chemosphere 46(8): 1147-1155.

Katsev S., Tsandev I., L'Heureux I., Rancourt D.G., 2006, Factors controlling long-term phosphorus efflux from lake sediments: Exploratory reactive-transport modeling, Chem. Geol. 234: 127-147.

Kisand A., 2005, Distribution of sediment phosphorus fractions in hypertrophic strongly stratified Lake Verevi, Hydrobiologia 547:433-39.

Kleeberg A., 1997, Interactions between benthic phosphorus release and sulphur cycling in Lake Scharmutzelsee (Germany), Water Air Soil Poll. 99: 391-399.

Koski-Vähälä J., Hartikainen H., 2001, Assessment of the risk of phosphorus loading due to resuspended sediment, J. Environ. Qual. 30:960-966.

Kowalczewska-Madura K., Dondajewska R., Gołdyń R., 2010, Total phosphorus and organic matter content in bottom sediments of lake under restoration measures with iron treatment, Limnol. Rev. 10(3-4): 139-145.

Lewandowski J., Schauser I., Hupfer M., 2003, Long term effects of phosphorus precipitations with alum in hypereutrophic Lake Süsser See (Germany), Water Res. 37(13): 3194-3204.

Lis J., Pasieczna A., 1995, Atlas geochemiczny Polski w skali 1:2500000 (Geochemical Atlas of Poland 1:2500000), PIG, Warszawa, 72 pp.

Lopez P., Navarro E., Marce R., Ordoñez J., Caputo L., Armengol J., 2006, Elemental ratios in sediments as indicators of ecological processes in Spanish reservoirs, Limnetica, 25(1-2): 499-512,

Łącka B., Starnawska E., Kuźniarski M., Chróst L., 1998, Mineralogy and geochemistry of the Lake Gościąż holocene sediments, [in] Ralska-Jasiewiczowa M., Goslar T., Madeyska T., Starkel L. (eds), Lake Gościąż, Central Po- 
land, Szafer Institute of Botany PAN, Karków: 124-128.

Manny B.A., Johnson W.C., Wetzel R.G., 1994, Nutrient additions by waterfowl to lakes and reservoirs: predicting their effects on productivity and water quality, Hydrobiologia 279/280: 121-132.

Marion L., Clergeau P., Brient L., Bertru G., 1994, The importance of avian-contributed nitrogen $(\mathrm{N})$ and phosphorus (P) to Lake Grand-Lieu, France, Hydrobiologia 279/280: 133-147.

Moore A., Reddy K.R., 1994, Role of Eh and pH on Phosphorus Geochemistry in Sediments of Lake Okeechobee, Florida, J. Environ. Qual. 23(5): 955-964.

Nriagu J., Dell C., 1974, Diagenetic formation of iron phosphates in recent lake sediments, Am. Mineral. 59: 934946.

Pulatsü S., Kırkagaç A., Iksal G., 2008, Sediment phosphorus characteristics in the Clearwater state of Lake Mogan, Turkey, Lakes Reserv. Res. Manag. 13: 197-205.

Reimann C., de Caritat P., 1998, Chemical elements in the environment, Springer-Verlag, Berlin-Heidelberg, 398 pp.

Reitzel K., Hansen J., Andersen F., Hansen K., Jensen H., 2005, Lake Restoration by Dosing Aluminum Relative to Mobile Phosphorus in the Sediment, Environ. Sci. Technol. 39: 4134-4140.

Ribeiro D.C., Martins G., Nogueira R., Cruz J.V., Brito A.G., 2008, Phosphorus fractionation in volcanic lake sediments (Azores- Portugal), Chemosphere 70(7): 12561263.

Rothe M., Frederichs T., Eder M., Kleeberg A., Hupfer M., 2014, Evidence for vivianite formation and its contribution to long-term phosphorus retention in a recent lake sediment: a novel analytical approach, Biogeosciences 11: 5169-5180.

Ruttenberg K.C., Ogawa N.O., Tamburini F., Briggs R.A., Colasacco N.D., Joyce E., 2009, Improved, high-throughput approach for phosphorus speciation in natural sediments via the SEDEX sequential extraction metod, Limnol. Oceanogr. Methods 7: 319-333.

Rzepecki M., 2010, The dynamics of phosphorus in lacustrine sediments: contents and fractions in relation to lake trophic state and chemical composition of bottom de- posits, Pol. J. Ecol. 58(3): 409-427.

Şahin Y., Demirak A., Keskin F., 2012, Phosphorus fractions and its potential release in the sediments of Koycegiz lake, Turkey, Lakes Reserv. Ponds 6(2):139-153.

Salminen R., Batista M., Bidovec M., Demetriades A., De Vivo B., De Vos W., Duris M., Gilucis A., Gregorauskiene V., Halamic J., Heitzmann P., Lima A., Jordan G., Klaver G., Klein P., Lis J., Locutura J., Marsina K., Mazreku A., O'Connor P., Olsson S., Ottesen R., Petersell V., Plant J., Reeder S., Salpeteur L., Sandström H., Siewers U., Steenfelt A., Tarvainen T., 2005, Geochemical Atlas of Europe. Part 1. Background information, methodology and maps, Geological Survey of Finland, Espoo, 526 pp.

Santiago, S. and R.L. Thomas., 1992, Phytoplankton utilization of phosphorus bound to suspended sediments from selected tributaries to Lake Geneva, J. Great Lakes Res. 18:372-389.

Søndergaard M., Jensen J.P., Jeppesen E., 2003, Role of sediment and internal loading of phosphorus in shallow lakes, Hydrobiologia 506-509: 135-145.

Taylor K.G., Hudson-Edwards K.A., Bennett A.J., Vishnyakov V., 2008, Early diagenetic vivianite [Fe3(PO4)2 $8 \mathrm{H} 2 \mathrm{O}]$ in a contaminated freshwater sediment and insights into zinc uptake: A $\mu$-EXAFS, $\mu$-XANES and Raman study, Appl. Geochem. 23(6): 1623-1633.

Wang C., Qian J., Guo Z., Zhao L., Li X., 2008, Vertical distributions of phosphorus fractions in sediments of three typical shallow urban lakes in P.R. China, Pol. J. Environ. Stud. 17:155-162.

Wetzel R., 2001, Limnology, Academic Press, San Diego, $1006 \mathrm{pp}$.

Xu D., Ding S., Li B., Bai X., Fan C., Zhang C., 2013, Speciation of organic phosphorus in a sediment profile of Lake Taihu I: Chemical forms and their transformation, J. Environ. Sci. 25(4): 637-644.

Yang L., Liu E., 2011, The Human Pollution Evaluation of Phosphorus in Surface Sediments of Nansihu Lake, Procedia Environ. Sci. 10: 918-921.

Zhu Y., Wu F., He Z., Guo J., Qu X., Xie F., Giesy J., Liao H., Guo F., 2013, Characterization of organic phosphorus in lake sediments by sequential fractionation and enzymatic hydrolysis, Environ. Sci. Tech. 47: 7679-7687. 
